\title{
POSTURAL STABILITY EXERCISE LEBIH MENINGKATKAN FLEKSIBILITAS LUMBAL DIBANDINGKAN STATIC STRETCHING EXERCISE PADA PENJAHIT DI KOTA DENPASAR
}

\author{
Ni Luh Putu Gita Karunia Saraswati', I Dewa Putu Sutjana ${ }^{2}$, Wahyuddin ${ }^{3}$, Ni Wayan \\ Tianing ${ }^{4}$, Luh Made Indah Sri Handari Adiputra ${ }^{5}$, Muh. Irfan ${ }^{6}$ \\ ${ }^{1}$ Program Studi Magister Fisiologi Olahraga Universitas Udayana, Denpasar \\ ${ }^{2,4,5}$ Fakultas Kedokteran Universitas Udayana, Denpasar \\ ${ }^{3}$ Fakultas Fisioterapi Universitas Esa Unggul, Jakarta \\ ${ }^{6}$ Program Studi Fisioterapi Stikes Aisyiyah Yogyakarta
}

\begin{abstract}
ABSTRAK
Pendahuluan: Karakteristik kerja penjahit seperti duduk statis dan membungkuk dapat memicu timbulnya keluhan seperti ketegangan otot area punggung bawah yang apabila tidak ditangani dapat menyebabkan terjadinya penurunan fleksibilitas lumbal.. Tujuan Penelitian: untuk membuktikan postural stability exercise lebih meningkatkan fleksibilitas lumbal dibandingkan static stretching exercise pada penjahit di Kota Denpasar. Metode: Design penilitian ini menggunakan eksperimental dengan rancangan pre dan post test control group design. Jumlah sampel penelitian sebanyak 30 orang yang kemudian dibagi menjadi 2 kelompok. Kelompok perlakuan I diberikan static stretching exercise, sedangkan Kelompok II diberikan postural stability exercise. Fleksibilitas lumbal diukur dengan modified-modified Schoober test. Hasil: Berdasarkan hasil Paired Sample t-test pada Kelompok I dan Kelompok II nilai $\mathrm{p}<0,05$ yang menyatakan bahwa terdapat perubahan yang signifikan setelah pemberian latihan pada masing-masing kelompok. Selanjutnya, uji perbandingan antara Kelompok 1 dengan Kelompok 2 menggunakan independent sample t-test dan didapatkan nilai $\mathrm{p}<0,05$. Hal ini menunjukkan ada perbedaan yang signifikan antara kelompok. Simpulan: postural stability exercise lebih meningkatkan fleksibilitas lumbal dibandingkan static stretching exercise pada penjahit di Kota Denpasar
\end{abstract}

Kata Kunci: fleksibilitas lumbal, static stretching exercise, postural stability exercise, penjahit.

\section{POSTURAL STABILITY EXERCISE MORE INCREASES LUMBAL FLEXIBILITY COMPARED TO STATIC STRETCHING EXERCISE IN TAILOR IN DENPASAR CITY}

\begin{abstract}
Background: Tailor work characteristics such as sitting static and bending can trigger complaints such as lower back area muscle tension which if left untreated can cause a decrease in lumbar flexibility. Purpose: to prove postural stability exercise is more to increase lumbar flexibility than static stretching exercise on tailors in Denpasar City. Method: This study was an experimental study with pre and post test control group design. The study sample consisted of 30 people divided into two groups. Group 1 given static stretching exercise, while Group 2 given postural stability exercise. Measurement of lumbar flexibility using a modified-modified Schoober test. Result: Paired Sample t-test in Group 1 and Group 2 showed p value $p<0.05$ which showed that there were significant changes after giving training to each group. Furthermore, a comparison test between Group 1 and Group 2 used independent sample t-test and obtained $p<0.05$. This result showed that there are significant differences between the two groups. Conclusion: postural stability exercise increases lumbar flexibility more than static stretching exercise for tailors in Denpasar City.
\end{abstract}

Keywords: lumbar flexibility, static stretching exercise, postural stability exercise, tailor. 


\section{PENDAHULUAN}

Garmen X adalah salah satu industri garmen berskala menengah yang berada di kota Denpasar, Provinsi Bali. Garmen X bergerak dibidang produksi kaos, polo, dan training. Karyawan khususnya penjahit bekerja pada hari Senin sampai Sabtu, dengan waktu kerja adalah selama 8-10 jam setiap harinya, apabila orderan sedang menumpuk dan harus mengejar deadline jam kerjanya bisa mencapai 12 jam dalam satu hari. Para penjahit memiliki waktu untuk beristrahat selama 1 jam selama jam kerja. Selama jam istirahat biasanya mereka isi dengan makan siang dan mengobrol dengan temantemannya.

Berdasarkan hasil wawancara yang dilakukan pada tenaga kerja penjahit di Modes Kartini Garmen menyatakan hasil adanya beberapa keluhan fisik seperti nyeri hingga keterbatas gerak yang mereka rasakan semenjak bekerja menjadi penjahit. Penjahit merupakan salah satu sumber daya penting yang dimiliki oleh industri garmen. Karakteristik pekerja penjahit dalam industri tekstil adalah duduk statis yang disertai dengan posisi bagian leher dan punggung sedikit membungkuk serta posisi siku maupun lutut yang ditekuk. ${ }^{1}$

Para pekerja di Eropa sebanyak 25$27 \%$ mengeluh merasakan sakit punggung dan sebanyak $23 \%$ merasakan nyeri otot. ${ }^{2}$ Berdasarkan data pada tahun 2005 yang didapat dari hasil studi Departemen Kesehatan, Keadaan di Indonesia menunjukkan angka 40,5\% pekerjaan dapat menyebabkan terjadinya penyakit. Keluhan yang umum yang dijumpai masyarakat diantaranya adalah nyeri punggung, dan diperkirakan mencakup $65 \%$ dari seluruh populasi. Kasus dilapangan yang terjadi pada penjahit diperoleh data sebanyak $82,5 \%$ penjahit mengalami keluhan rasa kurang nyaman semacam nyeri pada area pinggang, lalu $60 \%$ pada area bokong, $57,5 \%$, pada leher bagian bawah $47,5 \%$ dan pada leher bagian atas adalah $45 \%$. $^{3}$
Sikap duduk dengan jangka waktu yang relative lama dengan posisi leher dan punggung yang membungkuk yang diikuti dengan posisi lutut yang ditekuk berpotensi kepada terjadinya pemendekan otot-otot disekitarnya karena terjadi reaksi tegangan otot dalam waktu yang panjang hingga dapat menyebabkan keterbatasan range of motion (ROM) atau penurunan fleksibilitas jaringan sekitarnya. Fleksibilitas merupakan kemampuan seseorang untuk melakukan pergerakan dalam lingkup gerak sendi tanpa adanya keluhan. ${ }^{4}$

Fleksibilitas penting kaitannya untuk menentukan kemampuan fungsional seseorang sehari-harinya sehingga tercipta produktivitas kerja yang baik pula dalam kesehariannya, contohnya adalah fleksibilitas pada area lumbal. Fleksibilitas lumbal berperan penting dalam berbagai aktivitas misalnya memutar badan, mengangkat, membungkuk. Sehingga pada para penjahit yang dominan pekerjaannya didominasi dengan sikap duduk statis dengan jangka waktu yang panjang berisiko mengalami penurunan fleksibilitas lumbal atau area punggung bawah dan berkurangnya kemampuan fungsional dari area punggung bawah. Penelitian oleh Dewi pada tahun 2015 menunjukan hasil adanya hubungan yang signifikan antara posisi duduk statis dalam jangka waktu yang panjang dengan fleksibilitas lumbal pada pembatik di Surakarta. $^{4}$

Mengingat berisikonya seorang penjahit mengalami penurunan fleksibilitas pada lumbal, maka perlu dilakuan suatu usaha intervensi fisioterapi yang bertujuan untuk koreksi postural serta menjaga postur tubuh ataupun intervensi yang bertujuan untuk menjaga serta meningkatkan kelenturan otototot area punggung bawah. Salah satu contoh bentuk terapi latihan adalah static stretching exercise yang merupakan latihan peregangan yang bertujuan meningkatkan elastisitas otot, menambah lingkup gerak sendi, memperbaiki elastisitas jaringan sehingga dapat melakukan gerak yang efisien, mencegah cedera dan koreksi postur yang buruk. ${ }^{5}$ 
Perkembangan data terkini menyatakan terdapat suatu cara baru yang terkenal dengan aktifasi yang meliputi otototot core (inti). Fungsi utama otot core yaitu menjaga postur tubuh. Kepopuleran program latihan ini didasarkan pada keyakinan bahwa core strength dan endurance (inti kekuatan dan ketahanan) adalah hal terpenting untuk memelihara kesehatan punggung bawah dan untuk mencegah terjadinya cedera terutama dalam peningkatan aktivitas fungsional. Otot inti yang lemah atau tidak seimbang akan mengakibatkan adanya rasa sakit di daerah punggung bawah. ${ }^{6}$

Penelitian yang dilakukan oleh Wang, $d k k$ pada tahun 2012 terhadap 148 pasien dengan keluhan nyeri punggung bawah kronis dengan perlakuan latihan peregangan yang mengarahkan punggung kearah ekstensi atau lebih terkenal dengan sebutan back school exercise selama 4 minggu, menyatakan bahwa back school exercise lebih efektif dalam memperbaiki keterbatasan fungsional. ${ }^{7}$ Postural stability exercise pada kasus nyeri punggung bawah kronis dari berbagai jurnal penelitian sampai tahun 2011, menunjukan hasil bahwa postural stability exercise lebih efektif dalam menurunkan nyeri dan meningkatkan kemampuan fungsional pada pasien nyeri punggung bawah kronis. ${ }^{7}$

Penelitian terdahulu yang menyatakan bahwa postural stability exercise dan back school exercise adalah penelitian yang terpisah dan belum membandingkan kedua intervensi dalam mengurangi nyeri dan menuju pada peningkatan fungsional pada pasien nyeri punggung bawah, maka dari itu peneliti tertarik untuk membandingkan efektifitas postural stability exercise dengan static stretching exercise terhadap peningkatan fleksibilitas lumbal pada penjahit

\section{METODE PENELITIAN}

menggunakan modified-modified Schoober test (MMST).

Penelitian ini dilakukan di Garmen Modes Kartini pada Bulan Januari - Maret 2018. Penelitian dilakukan sebanyak 3 kali seminggu selama 6 minggu. Sampel berjumlah 15 orang di masing-masing kelompok, yang diseleksi dari populasi penjahit di Modes Kartini Garmen.

Dalam menganalisa data yang didapat dari pengukuran fleksibilitas lumbal dengan menggunakan program perangkat lunak computer. Tahapan yang dilakukan dalam menganalisa data yaitu : (1) Statistik Deskriptif Statistik deskriptif untuk menganalisis umur, jenis kelamin, dan lama bekerja, (2) Uji normalitas dengan Saphiro Wilk test, (3) Uji Homogenitas menggunakan Levene's test, (4) Uji Hipotesis pada masing-masing kelompok menggunakan Paired t-test dan uji perbandingan antara 2 kelompok menggunakan Independent t-test. Kedua uji ini adalah test parametric karena data pada kedua kelompok berdistribusi normal.

\section{HASIL PENELITIAN}

\section{Karakteristik Subjek Penelitian}

Tabel 1.

Karakteristik Sampel

\begin{tabular}{|c|c|c|}
\hline \multirow{2}{*}{ Karakteristik } & \multicolumn{2}{|c|}{ Nilai Rerata dan Simpang Baku } \\
\hline & Kel. 1 & Kel. 2 \\
\hline Umur (Th) & $24,6 \pm 2,87$ & $26,26 \pm 3,45$ \\
\hline IMT $\left(\mathrm{Kg} / \mathrm{m}^{2}\right)$ & $21,24 \pm 1,43$ & $20,97 \pm 1,32$ \\
\hline Lama Bekerja (Th) & $3,86 \pm 1,35$ & $3,80 \pm 1,47$ \\
\hline
\end{tabular}

Berdasarkan Tabel 1 menunjukkan karakteristik sample berdasarkan umur, IMT, dan Lama Bekerja. Berdasarkan dari nilai rerata pada masing-masig variable telah didaptkan hasil yang sudah sesuai berdasarkan kriteria inklusi penelitian.

\section{Uji Normalitas dan Homogenitas}

Tabel 2.

Uji Normalitas dan Homogenitas

\begin{tabular}{|c|c|c|c|c|}
\hline \multirow{4}{*}{$\begin{array}{l}\text { Klp } \\
\text { Data }\end{array}$} & \multirow{4}{*}{ Gerakan } & \multicolumn{2}{|c|}{ Normalitas $^{\mathrm{a}}$} & \multirow[t]{2}{*}{ Homogenitas } \\
\hline & & Klp 1 & Klp 2 & \\
\hline & & Nilai & Nilai & Nilai \\
\hline & & $\mathrm{p}$ & $\mathrm{p}$ & $\mathrm{p}$ \\
\hline Sebelum & Fleksi & 0,29 & 0,17 & 0,25 \\
\hline
\end{tabular}




\begin{tabular}{ccccc}
\cline { 2 - 5 } Pelatihan & Ekstensi & 0,61 & 0,16 & 0,88 \\
Sesudah & Fleksi & 0,71 & 0,66 & 0,24 \\
Pelatihan & Ekstensi & 0,63 & 0,40 & 0,90 \\
\hline
\end{tabular}

a Uji Normalitas dengan Saphiro Wilk test

b Uji Homogenitas dengan Levene's test

Berdasarkan data pada tabel 2 menunjukkan bahwa kelompok perlakuan I dan II dan II berdistribusi secara normal karena memiliki nilai $\mathrm{p}>0,05$ baik pada kondisi sebelum perlakuan atau sesudah perlakuan. Jadi, uji statistik yang digunakan untuk pengujian selanjutnya menggunakan uji statistik parametrik.

Uji homogenitas diuji dengan Levene's test, maka dapat disimpulkan data yang diambil setelah perlakuan ataupun sebelum perlakuan pada kelompok perlakuan I dan II bersifat homogen karena nilai p>0,05.

\section{Uji Beda Rerata Fleksibilitas Lumbal Sebelum dan Sesudah Latihan pada Masing- Masing Kelompok}

Tabel 3.

Paired Sample t-test

\begin{tabular}{llcc}
\hline \hline \multicolumn{2}{c}{ Gerakan } & \multicolumn{2}{c}{ Kelompok Data } \\
\cline { 3 - 4 } & & Klp 1 & Klp 2 \\
\hline $\begin{array}{l}\text { Rerata } \\
\text { Lebelum }\end{array}$ & Fleksi & $19,96 \pm 1,2$ & $19,53 \pm 1,5$ \\
& & & \\
\hline $\begin{array}{l}\text { Rerata } \\
\text { Sesudah }\end{array}$ & Ekstensi & $13,23 \pm 0,4$ & $12,9 \pm 0,54$ \\
Latihan & Ekstensi & $21,36 \pm 1,1$ & $22,33 \pm 1,3$ \\
\hline Nilai p & Fleksi & 0,001 & 0,001 \\
& Ekstensi & 0,001 & 0,001 \\
\hline
\end{tabular}

Dilihat berdasarkan data pada tabel 3 menunjukan data hasil beda rerata peningkatan fleksibilitas lumbal sebelum dan setelah intervensi pada kelompok 1 baik pada kemampuan gerak fleksi atau gerak ekstensi didapatkan nilai $\mathrm{p}<0,05$ yang berarti bahwa terdapat perbedaan yang bermakna pada peningkatan fleksibilitas lumbal sebelum dan setelah latihan pada static stretching exercise.

Hasil perbedaan rerata pada kelompok II juga dapat dilihat pada tabel 3 yang menunjukan hasil, uji hipotesis sebelum dan setelah intervensi pada kelompok 2 baik pada kemampuan gerak fleksi atau gerak ekstensi menggunakan paired sample t-test didapatkan nilai $\mathrm{p}<0,05$ yang berarti bahwa terdapat perbedaan yang bermakna pada peningkatan fleksibilitas lumbal sebelum dan setelah perlakuan pada postural stability exercise.

\section{Uji Komparasi Fleksibilitas Lumbal Sebelum dan Sesudah Latihan Pada Kedua Kelompok Penerapan}

Tabel 4.

Independent Sample t-test

\begin{tabular}{|c|c|c|c|c|c|}
\hline & & Klp & $\mathrm{N}$ & Rerata \pm SB & $\begin{array}{c}\text { Nilai } \\
\mathrm{p}\end{array}$ \\
\hline \multirow{4}{*}{$\begin{array}{l}\text { Sebelum } \\
\text { Latihan }\end{array}$} & \multirow{2}{*}{$\begin{array}{l}\text { Fleksi } \\
(\mathrm{cm})\end{array}$} & 1 & 15 & $19,96 \pm 1,2$ & \multirow{2}{*}{0,408} \\
\hline & & 2 & 15 & $19,53 \pm 1,6$ & \\
\hline & \multirow{2}{*}{$\begin{array}{l}\text { Ekstensi } \\
\text { (cm) }\end{array}$} & 1 & 15 & $13,23 \pm 0,5$ & \multirow{2}{*}{0,089} \\
\hline & & 2 & 15 & $12,90 \pm 0,5$ & \\
\hline \multirow{4}{*}{$\begin{array}{l}\text { Sesudah } \\
\text { Latihan }\end{array}$} & \multirow{2}{*}{$\begin{array}{c}\text { Fleksi } \\
(\mathrm{cm})\end{array}$} & 1 & 15 & $21,36 \pm 1,1$ & \multirow{2}{*}{0,031} \\
\hline & & 2 & 15 & $22,33 \pm 1,4$ & \\
\hline & \multirow{2}{*}{$\begin{array}{c}\text { Ekstensi } \\
(\mathrm{cm})\end{array}$} & 1 & 15 & $12,13 \pm 0,4$ & \multirow{2}{*}{0,001} \\
\hline & & 2 & 15 & $11,03 \pm 0,7$ & \\
\hline \multirow[t]{4}{*}{ Selisih } & \multirow{2}{*}{$\begin{array}{c}\text { Fleksi } \\
(\mathrm{cm})\end{array}$} & 1 & 15 & $1,4 \pm 0,5$ & \multirow{2}{*}{0,001} \\
\hline & & 2 & 15 & $2,8 \pm 1,1$ & \\
\hline & \multirow{2}{*}{$\begin{array}{l}\text { Ekstensi } \\
\text { (cm) }\end{array}$} & 1 & 15 & $1,1 \pm 0,47$ & \multirow{2}{*}{0,001} \\
\hline & & 2 & 15 & $1,8 \pm 0,61$ & \\
\hline
\end{tabular}

Hasil Uji Independent t-test dapat dilihat pada Tabel 5.4 yang menunjukan hasil perhitungan selisih fleksibilitas lumbal baik pada kemampuan gerak fleksi ataupun gerak ekstensi yang diperoleh nilai $\mathrm{p}<0,05$ pada selisih antara sebelum dan sesudah latihan. Hal ini menunjukkan adanya perbedaan yang bermakna antara Kelompok 1 (static stretching exercise) dan Kelompok 2 (postural stability exercise). Pada Kelompok 1 terjadi peningkatan fleksibilitas lumbal sebesar 1,4 pada kemampuan fleksi dan 1,1 pada kemampuan ekstensi. Pada kelompok 2 terjadi peningkatan fleksibilitas lumbal sebesar 2,8 pada kemampuan fleksi dan 1,8 pada kemampuan ekstensi.. Dari data yang didapatkan, dapat disimpulkan bahwa pada Kelompok 2 terjadi peningkatan fleksibilitas lumbal yang lebih baik dibandingan dengan kelompok 1. 


\section{PEMBA $\overline{A H A S A N}$}

\section{Static Stretching Exercise dapat Meningkatkan Fleksibilitas Lumbal Pada Penjahit.}

Berdasarkan beberapa kajian teori, static stretching exercise merupakan salah satu bentuk latihan yang diberikan untuk memperbaiki sirkulasi, mengurangi tegangan otot, meningkatkan elastisitas jaringan sekitar, mengurangi nyeri otot, dan mencegah cedera. Target utama diberikannya static stretching exercise pada penjahit adalah membantu memberikan penguluran pada otot-otot yang mengalami ketegangan atau kekakuan akibat posisi kerja yang menyebabkan terjadinya kerja yang tidak seimbang (imbalance) pada seluruh tubuh terutama area leher, punggung, dan paha belakang untuk mempertahankan postur tubuh saat duduk membungkuk di mesin jahit. ${ }^{5}$

Static stretching exercise pada penelitian ini bertujuan untuk meningkatkan kemampuan regangan otot-otot yang berperan dalam fleksibilitas lumbal. Kurangnya fleksibilitas pada area hamstring, hip fleksor, dan area gluteal dapat memicu terjadinya nyeri pada punggung bawah dan terbatasnya gerakan pada area punggung bawah. Bila saat melakukan static stretching exercise pasien merasakan nyeri, maka ada kemungkinan kemampuan fleksibilitas ototnya mengalami penurunan. Static stretching exercise yang dilakukan secara tepat dalam jangka waktu tertentu akan berdampak pada peningkatkan elastisitas otot, mengurangi ketegangan otot, rileksasi otot dan memperbaiki struktur otot.. Static stretching exercise juga akan dapat memperbaiki sistem sirkulasi darah sehingga mengurangi risiko terjadinya spasme atau ketegangan otot yang dapat menghambat gerakan dan fungsi sendi. ${ }^{8}$

\section{Postural Stability Exercise dapat Meningkatkan Fleksibilitas Lumbal Pada Penjahit.}

Berdasarkan beberapa kajian teori, postural stability exercise merupakan salah satu latihan yang diberikan untuk membentuk postural yang baik. Sasaran utama latihan postural stability adalah otot yang letaknya lebih dalam pada area abdomen, spine, pelvic, dan shoulder. Jadi prinsip dari postural stability exercise adalah untuk melatih dan mengaktivasi otot-otot core yang merupakan otot-otot postural tubuh. Teraktivasinya otototot core akan meningkatkan stabilitas postural. ${ }^{9}$

Teraktivasinya otot-otot core akan meningkatkan intraabdominal pressure (IAP) untuk menahan trunk, menurunkan beban pada otot-otot spine dan meningkatkan stabilitas trunk. Kontraksi dari otot-otot diafragma dan abdominal, seperti transverses abdominalis meningkatkan IAP dan tekanan fascia thorakolumbal. Jadi kontraksi dari diafragma, pelvic floor, dan transversus abdominalis berperan dalam regulasi dari IAP dan menyediakan stabilitas postural pada anterior lumbopelvic sehingga disebut deep core dan bekerja secara automatis tanpa disadari serta menjadi awal suatu gerakan. Dalam hal ini, sebelum menggerakkan anggota gerak, akan diawali dengan peningkatan stabilitas dari spine (core of the body) terlebih dahulu. ${ }^{10}$

Dalam postural stability exercise target utama adalah pelatihan ulang fungsi otot yang lebih dalam atau yang biasa disebut deep musle dalam seperti transver abdominis dan multifidus yang kemudian hal ini dapat menstimulasi aktivitas deep muscle dan global muscle sesuai tugasnya. Koordinasi deep muscle sangat penting dalam gerak bagian intervertebra dari tulang belakang dan pelvic. Kedua otot lumbopelvic, yaitu transver abdominis dan multifidus memiliki kemampuan yang minimal untuk menggerakkan tulang belakang. Transver abdominis berperan dalam mempertahankan stabilitas tulang belakang dengan cara meningkatkan tekanan intra abdominal. Peningkatan tekanan intra abdominal tersebut akan menyebabkan ketegangan dari tulang belakang sehingga tulang belakang menjadi stabil. ${ }^{11}$

Multifidus adalah deep muscle yang memiliki peran sangat kecil untuk mengontrol tulang belakang, tetapi multifidus dapat mengendalikan gerakan intervertebra. 
Kesimpulannya dengan teraktivasinya deep muscle atau otot-otot core kerja dari global muscle akan menjadi ebih ringan untuk mempertahankan postural tubuh ketika bekerja dengan posisi duduk yang membungkuk, sehingga kerja otot yang imbalance akan berkurang dan mencegah terjadinya kekakuan atau ketegangan otot. ${ }^{9}$

Penelitian yang telah dilakukan oleh Wang, $d k k$ pada tahun 2012 tentang efektifitas postural stability exercise dengan general exercise pada kasus nyeri punggung bawah kronis penelitian dari tahun 1970 sampai 2011, juga mendukung hasil yang dimana didapatkan bahwa postural stability exercise lebih efektif dalam menurunkan nyeri serta meningkatkan kemampuan fungsional pada pasien nyeri punggung bawah kronis. ${ }^{7}$

\section{Terdapat Perbedaan Static Stretching Exercise dengan Postural Stability Exercise terhadap peningkatan Fleksibilitas Lumbal}

Berdasarkan hasil independent t-test, diperoleh nilai selisih peningkatan fleksibilitas lumbal pada Kelompok 1 sebesar $1,4 \pm 0,5$ pada kemampuan gerak fleksi dan $1,1 \pm 0,47$ pada kemampuan gerak ekstensi. Lalu pada kelompok 2 diperoleh nilai selisih fleksibilitas lumbal adalah 2,8 $\pm 1,1$ pada kemampuan gerak fleksi dan 1,8 $\pm 0,61$ pada kemampuan gerak ekstensi.

Selain nilai rerata selisih diperoleh pula nilai $\mathrm{p}<0,05$ yang menyatakan bahwa terdapat perbedaan yang bermakna antara Kelompok 1 dan Kelompok 2. Jadi dapat ditarik kesimpulan bahwa terdapat perbedaan efektivitas antara static stretching exercise dengan postural stability exercise dalam meningkatkan fleksibilitas lumbal pada penjahit. Dimana dari hasil selisih beda rerata diatas didapatkan hasil postural stability exercise lebih efektif dalam meningkatkan fleksibilitas lumbal. Berdasarkan hasil penelitian ini, maka hipotesis ketiga yang menyatakan bahwa terdapat perbedaan efektifitas antara static stretching exercise dengan postural stability exercise adalah terbukti

$$
\text { Posisi statis dalam menjahit }
$$
merupakan salah satu faktor penyebab terjadinya keluhan musculoskeletal, salah satu contohnya adalah posisi duduk lama atau duduk statis saat menjahit. Duduk statis dalam jangka waktu yang lama dan berdampak kerusakan jaringan pada vertebra lumbal. Posisi yang salah dalam waktu yang lama akan menyebabkan ketegangan atau spasme otot-otot area punggung bawah dan ketegangan ligamentum tulang belakang. Kategangan otot dalam jangka waktu yang lama akan menyebabkan terjadinya vasokonstriksi pembuluh darah yang nantinya akan berdampak pada terjadinya iskemia, yang akan menimbulkan rasa kurang nyaman atau nyeri sehingga penderita akan membatasi adanya gerakan yang dapat menimbulkan nyeri hingga penurunan produktivitas. ${ }^{12}$

Pada posisi duduk statis dengan postur leher dan punggung yang membungkuk serta posisi lutut yang ditekuk terjadi pemendekan otot-otot disekitarnya karena terjadi reaksi tegangan otot dalam waktu yang panjang. Posisi postur tubuh yang kurang tepat juga menyebabkan terjadi efek proteksi dari otototot area vertebra untuk dapat menjaga keseimbangan stabilitas postural, sehingga timbul manifestasi penggunaan berlebihan atau overuse pada salah satu sisi otot. Susunan muskuloskeletal tupada vertebra akan mengalami gangguan dan menimbulkan keterbatasan LGS hingga berkurangnya fleksibilitas tubuh utamanya pada bagian punggung bawah, yang berdampak pada terganggunya aktivitas sehari-hari. ${ }^{12}$

Pada posisi duduk statis dengan jangka waktu yang panjang terjadi muscle imbalance yang dimana artinya selama posisi statis yang lama akan menyebabkan kerja otot yang tidak seimbangan antara agonis dan antagonis. Ketidakseimbangan kerja otot ini terjadi karena mekanisme proteksi untuk mempertahankan postural tubuh saat posisi duduk membungkuk ke depan oleh penjahit.

Pada Kelompok 1 terjadi peningkatan fleksibilitas lumbal sebesar 1,4 pada kemampuan fleksi dan 1,1 pada kemampuan ekstensi. Pada kelompok 2 terjadi peningkatan fleksibilitas lumbal sebesar 2,5 pada kemampuan fleksi dan 1,8 pada kemampuan ekstensi.. Dari data yang didapatkan, dapat disimpulkan bahwa pada 
Kelompok 2 terjadi peningkatan fleksibilitas lumbal yang lebih baik dibandingkan dengan kelompok 1.

Berdasarkan kajian teori yang ada dan penelitian yang telah ada dapat diambil sebuah kesimpulan bahwa postural stability exercise dapat meningkatkan fleksibilitas lumbal dengan meningkatkan aktivasi pada otot-otot core sehingga terjadi kontrol postural dan mengurangi kinerja dari global muscle sehingga potensi terajdinya kinerja otot yang tidak seimbang dapat dikurangi. Pada static stretching exercise dapat meningkatkan fleksibilitas lumbal dengan konsep penguluran pada otot-0tot yang mengalami ketegangan akibat kerja yang tidak seimbang. Sehingga dengan penguluran diharapkan dapat meningkatkan elastisitas jaringan dan melancarkan sirkulasi. Namun dari pemaparan kajian teori dikatakan postural stability exercise lebih efektif karena aktivasi otot-otot core yang baik akan jauh lebih dapat meningkatkan kontrol postural dan mengurangi terjadinya potensi muscle imbalance pada penjahit.

\section{KETERBATASAN PENELITIAN}

1. Penelitian ini baru menyimpulkan peningkatan fleksibilitas lumbal dalam untuk jangka pendek saja. Penelitian selanjutnya diharapkan untuk menambah waktu pelatihan untuk melihat efisiensi dan efektifitas pelatihan dalam jangka panjang, serta melakukan follow up kepada subjek penelitian agar dapat dilakukan sebagai usaha preventif dan mengevaluasi yang berhubungan dengan aktivitas fungsional mereka.

2. faktor aktivitas fisik yang dilakukan oleh sampel di luar jadwal penelitian tidak dapat dikontrol, Oleh karena itu penelitian selanjutnya diharapkan untuk mengontrol variabel ini untuk mendapatkan hasil yang lebih akurat.

\section{SIMPULAN}

1. Pemberian static stretching exercise dapat meningkatkan kemampuan fleksibilitas lumbal pada penjahit.
2. Pemberian postural stability exercise dapat meningkatkan kemampuan fleksibilitas lumbal pada penjahit.

3. Postural stability exercise lebih meningkatkan fleksibilitas lumbal dibandingkan static stretching exercise pada penjahit di Kota Denpasar

\section{DAFTAR PUSTAKA}

1. Polajnar, A; Marjan, L; dan Nataza, V.H. $2010 \quad$ Muscular-Skeletal Diseases Require Scientifically Designed Sewing Workstations. University of Maribror, Faculty of Mechanical Enginering, Slovenia.

2. Pulat, B.M. 2006. Fundamentals of Industrial Ergonomics. New Jersey: Prentice Hall.

3. Rahim, A. H. 2012. Vertebra. Jakarta: CV. Sagung Seto.

4. Dewi,F.K.2015. Hubungan Duduk Lama Statis dalam Membatik dengan Fleksibilitas Lumbal di Perusahaan Batik Danar Hadi Surakarta. Skripsi. Surakarta:Program Studi Fisioterapi Fakultas Ilmu Kesehatan Universitas Muhammadiyah Surakarta.

5. Pulcheria, Meryl \& Muliartha. 2016. Fleksibilitas Mahasiswa Universitas Udayana yang berlatih taichi lebih baik daripada yang tidak berlatih tai chi. Denpasar : Fakultas Kedokteran Universitas Udayana.

6. Pramita, I. 2014. Core Stability Exercise Lebih Baik Meningkatkan Aktivitas Fungsional Dari Pada William's Flexion Excercise Pada Pasien Nyeri Punggung Bawah Miogenik. Tesis. Denpasar: Program Pascasarjana Studi Fisiologi Olahraga Universitas Udayana.

7. Wang, X. Q., J.J. Zheng, Z. W. Yu, Xia Bi, S. J. Lou, J. Liu, B. Cai, Y. H. Hua, M. Wu, M. L. Wei, H. M. Shen, Y. Chen, Y. J. Pan, G. H. Xu and P. J. Chen. 2012. A Meta-Analysis of Core Stability Exercise versus General Exercise for Chronic Low Back Pain. PLOSONE 7(12): PROSPERO. 
Diaakses 18 September 2017 melalui http://www.ncbi.nlm.nih.gov/pmc/arti cles/PMC3524111/pdf/pone.0052082. pdf

8. Borrestein \& Wissel. 2004. Low Back Pain Medical Diagnosis and comprehensive management. WB Saunders Company. Philadelphia.

9. Irfan, M. 2012. Fisioterapi Bagi Insan Stroke edisi pertama. Yogjakarta: Graha Ilmu Hal: 22-52.

10. Frankl, D. 1999. Anatomical Limitations of Flexibility : Physiological Basis of Flexibility.. Los Angeles: Department of Kinesiology and Physical Education.

11. Akutota, V., Ferreiro, A., Moore, T., and Fredericson, M. 2008. Core Stability Exercise Principle. Current Sport Medicine Reports, 7(1), 39-44

12. Meliala, L \& Pinzon, R. 2004. Patofisiologi dan Penatalaksanaan Nyeri Pinggang Bawah. Dalam: Meliala L, Rusdi I, Gofir A, editor. Pain Symposium: Towards Mechanim Based Treatment, Jogjakarta, hal. 109116. 